\title{
PENGEMBANGAN PRODUK ASURANSI MITRA MABRUR PLUS AJB BUMIPUTERA 1912 DENGAN MEMPARTISI DANA TABARRU
}

\author{
Rini Cahyandari', Riva Lesta Ariany', Tika Karlina Rachmawati3, Nurul \\ Hidayah Eka Putri4, Hasniah Aliah5, Rahayu Kariadinata', Adam Malik ${ }^{7}$ \\ 1,4 Jurusan Matematika, Fakultas Sains dan Teknologi, UIN Sunan Gunung Djati \\ Bandung, Jl. A.H Nasution 105, Bandung, Indonesia \\ 2,3,6 Prodi Pendidikan Matematika, Fakultas Tarbiyah dan Keguruan, UIN Sunan \\ Gunung Djati Bandung, Jl A.H Nasution 105, Bandung, Indonesia \\ 5 Jurusan Fisika, Fakultas Sains dan Teknologi, UIN Sunan Gunung Djati Bandung, Jl. \\ A.H Nasution 105, Bandung, Indonesia \\ 7Prodi Pendidikan Fisika, Fakultas Tarbiyah dan Keguruan, UIN Sunan Gunung Djati \\ Bandung, Jl A.H Nasution 105, Bandung, Indonesia
}

E-mail:rini_cahyandari@uinsgd.ac.id

\begin{abstract}
ABSTRAK
Penelitian ini bertujuan untuk mengembangkan produk asuransi Mitra Mabrur Plus sehingga lebih banyak manfaat yang diperuntukkan bagi nasabah dan ahli warisnya, selain itu penelitian ini bertujuan untuk mengetahui respon nasabah yang terikat dengan polis asuransi mitra mambrur plus mengenai pengembangan produk yang dilakukan. Penelitian dilakukan dengan membuat ilustrasi data asuransi, menerjemahkan, membuat model integrasi, melakukan partisi serta mencari factor-faktor yang mempengaruhi. Sedangkan untuk mengetahui respon dari pengembangan produk asuransi Mitra Mabrur Plus ini, penyebaran kuesioner ditujukan kepada para nasabah yang terikat dengan polis asuransi Mitra Mabrur Plus. Hasil penelitian menghasilkan table partisi dan integrasi asuransi syariah, dan hasil kuesioner menunjukkan bahwa kesediaan untuk menambah jumlah unit merupakan faktor signifikan yang mempengaruhi nasabah untuk menambah jumlah unit.
\end{abstract}

Kata kunci: Asuransi Syariah, Regresi, Manfaat Tambahan, Partisi Dana Tabarru, Tabel Integrasi

\begin{abstract}
This study aims to develop Mitra Mabrur Plus insurance products so that more benefits are intended for customers and their heirs, besides that this study aims to determine the response of customers who are tied to the mambrur partner insurance policy regarding product development carried out. The research was conducted by illustrating insurance data, translating, making integration models, partitioning and looking for influencing factors. While to find out the response from the development of Mitra Mabrur Plus insurance products, the distribution of questionnaires was aimed at customers who were bound by Mitra Mabrur Plus insurance policy. The results of the study resulted in the partition table and the integration of Islamic insurance, and the results of the questionnaire showed that the willingness to increase the number of units was a significant factor affecting customers to increase the number of units.
\end{abstract}

Keywords: Syariah insurance, regression, additional benefits, tabarru fund partition, integration table 
Rini Cahyandari, Riva Lesta Ariany,

Tika Karlina Rachmawati, Nurul Hidayah Eka Putri, Hasniah Aliah, Rahayu Kariadinata, Adam Malik

\section{PENDAHULUAN}

Pada zaman sekarang kata "asuransi" bukanlah merupakan hal yang asing lagi bagi masyarakat. Banyaknya minat masyarakat yang mengandalkan asuransi sebagai jaminan kehidupan bagi masa depan mereka membuat perkembangan perusahaan asuransi cukup pesat.

Asuransi merupakan sebuah lembaga keuangan yang berbentuk non-bank dan terorganisir dalam sebuah perusahaan. Pengelolaan dana merupakan aspek dan bentuk terbesar dari perusahaan asuransi. Seiring berjalannya waktu, perusahaan asuransi syariah pun mulai bermunculan. Bahkan, tidak sedikit perusahaan asuransi konvensional yang ikut menyediakan program asuransi syariah.

Sejarah terbentuknya asuransi syariah di dunia dimulai pada tahun 1979 ketika sebuah perusahaan asuransi jiwa di Sudan, yaitu Sudanese Islamic Insurance pertama kali memperkenalkan asuransi syariah. Pada tahun yang sama sebuah perusahaan asuransi jiwa di Uni Emirat Arab juga memperkenalkan asuransi syariah di wilayah Arab. Tahun 1981 sebuah perusahaan asuransi jiwa Swiss, bernama Dar Al-Maal Al-Islami memperkenalkan asuransi syariah di Jenewa, bersamaan dengan munculnya asuransi syariah kedua di Eropa yang diperkenalkan oleh Islamic Takafol Company di Luksemburg pada tahun 1983. Selanjutnya, pada tahun yang sama perusahaan asuransi syariah bernama Islamic Takafol dan Re-Takafol Company juga didirikan di Kepulauan Bahamas. Demikian juga di Bahrain, sebuah perusahaan asuransi jiwa berbasis syariah, yaitu Syarikat Al-Takafol Al-Islamiah Bahrain didirikan di tahun yang sama (Puspitasari, 2011).

Di Asia, asuransi syariah pertama kali diperkenalkan oleh Malaysia pada tahun 1985 melalui sebuah perusahaan asuransi jiwa bernama Takaful Malaysia, yang selanjutnya menjadi inspirasi berdirinya asuransi Islam di Brunei, Singapura dan Indonesia. Di ASEAN, syarikat Takaful Malaysia Berhad yang berdiri tanggal 29 November 1984 merupakan pelopor asuransi Islam sekaligus merupakan asuransi dengan prinsip-prinsip islam terbesar di ASEAN (Sula, 2004).

Perkembangan asuransi syari'ah di Indonesia dimulai pada tahun 1994 dengan berdirinya PT Syarikat Takaful Indonesia (STI) yang dimotori oleh Ikatan Cendekiawan Muslim Indonesia (ICMI) melalui Yayasan Abdi Bangsa, Bank Muamalat Indonesia, PT Asuransi Jiwa Tugu Mandiri, Departemen Keuangan RI, serta beberapa pengusaha muslim Indonesia (Puspitasari, 2011). Asuransi syari'ah dapat menjadi alternatif pilihan proteksi bagi pemeluk agama Islam yang menginginkan pengelolaannya sesuai dengan hukum Islam. Asuransi syari'ah ini juga bisa menjadi pilihan bagi pemeluk agama lain yang memandang konsep syari'ah adil bagi mereka, di mana syari'ah adalah sebuah prinsip atau sistem yang bersifat universal sehingga dapat dimanfaatkan oleh siapapun. Oleh karenanya perkembangan asuransi syariah menunjukkan kemajuan yang cukup baik dan bisa dilihat dari banyaknya asuransi konvensional yang membuka divisi syari'ah dan perkembangan perbankan syariah yang secara otomatis menuntut peranan asuransi syari'ah untuk pengamanan aset dan transaksi perbankan.

Perkembangan asuransi syari'ah dimulai pada tahun 1994 (Cahyandari, Ariany, \& Sukono, 2018) dengan berdirinya PT Syarikat Takaful Indonesia (STI) yang dimotori oleh Ikatan Cendekiawan Muslim Indonesia (ICMI) melalui Yayasan Abdi Bangsa, Bank Muamalat Indonesia, PT Asuransi Jiwa Tugu Mandiri, Departemen Keuangan RI, serta beberapa pengusaha muslim Indonesia. Tahun 2014 AASI (Asosiasi Asuransi Syari'ah Indonesia) menyakini sebagai tahun asuransi syari'ah Indonesia, karena faktor pertumbuhan yang berada di atas asuransi konvensional. Desember 2013 tercatat pertumbuhan asuransi syari'ah sebesar $43 \%$, sedangkan pertumbuhan asuransi konvensional hanya 20\%. Artinya asuransi syari'ah memiliki potensi yang sangat besar untuk terus berkembang di masa yang akan datang. 
Asuransi syariah sendiri memiliki pengertian suatu pengaturan pengelolaan resiko yang memenuhi ketentuan syariah, tolong menolong secara mutual yang melibatkan peserta dan perusahaan asuransi sebagai operator.

Dalam praktiknya, asuransi syariah menggunakan beberapa jenis akad, diantaranya adalah akad mudharabbah, akad wakalah, dan akad hybrid yang merupakan gabungan dari akad mudharabbah dan akad wakalah.

Pengembangan model tentang mekanisme pengelolaan dana premi pada asuransi syari'ah menunjukkan kemajuan yang sangat baik dengan munculnya model mudharabah, wakala, Hybrid(Puspa Liza Ghazali, 2011),(Puspa Liza Ghazali, Mohd, Muhamad, Ahmad, \& Mamat, 2012) akan tetapi model yang dimaksud di sini adalah model operasional berupa skema dari mekanisme pengelolaan dana premi. Model hybrid merupakan penggabungan dari kedua model mudharabah dan wakalah, di mana besaran biaya wakalah dirubah berdasarkan kontribusi dan bagi hasil pada investasi.Model ini sebagian besar digunakan di perusahaan asuransi syariah di Indonesia karena dianggap cukup adil untuk pemegang polis dan perusahaan asuransi. Pengelolaan dana premi menggunakan model hybrid membagi akun ke dalam tiga rekening, yaitu rekening tabungan, rekening tabarru dan rekening ujrah.

Asuransi syariah memiliki berbagai macam produk yang beragam. Salah satunya adalah asuransi haji. Asuransi haji merupakan asuransi yang bertujuan untuk menyisihkan dana tabungan haji secara teratur serta menyediakan dana bagi hasil dan asuransi perlindungan. Pada produk asuransi haji, manfaat yang diperoleh hanya berupa dana klaim kematian saja.

Sebelumnya penulis pernah melakukan pengembangan model integrasi dengan menggunakan akad mudharabbah dengan cara mempartisi dana premi bulanan yang dibayarkan oleh peserta setiap bulannya. Peserta membayarkan dana premi bulanan, yang mana dana premi bulanan tersebut akan dibagi kedalam 3 bagian, yaitu dana investasi peserta, partisi dana pensiun, dan partisi dana manfaat. Pada kajian sebelumnya, partisi yang digunakan adalah partisi dana manfaat demi memaksimalkan dana manfaat yang akan diterima oleh peserta asuransi.

Perkembangan model matematika tentang pengelolaan dana asuransi syariah di Malaysia sudah sangat beragam dikarenakan penelitian yang dilakukan terus berkelanjutan dari tahun ke tahun. Pada tahun 2011, paper dengan judul: "Mathematical Modelling in Family Takaful"membahas tentang model matematika untuk asuransi syariah keluarga, yaitu model mudharabah dan model wakalah, yang selanjutnya disebut dengan model existing(Puspa Liza Ghazali, 2011). Selanjutnya, tahun 2012 paper dengan judul: "Implementation of Integration Model for All" membahas tentang kelemahan model existing, yaitu informasi tentang pengelolaan dana yang diterima oleh calon dan atau peserta asuransi kurang transparan, sehingga pada paper ini diajukan perbaikan model, yang selanjutnya disebut dengan model integrasi (Puspa Liza Ghazali et al., 2012). Tahun 2015 paper dengan judul: "Optimization of Integration Model in Family Takaful" membahas tentang pengembangan model matematika pada asuransi syariah keluarga, di mana calon dan atau peserta asuransi diberi kesempatan untuk dapat membeli produk asuransi lebih dari satu, dan manfaat yang diterima pun beragam, tidak hanya untuk peseta asuransi saja tetapi juga untuk ahli warisnya (P. L Ghazali, 2015).

Oleh sebab itu penulis merasa tertarik untuk melakukan pengembangan model integrasi dengan menggunakan akad hybrid pada asuransi syariah demi untuk mendapatkan rancangan produk baru dan penulis juga merasa tertarik untuk mengetahui apa saja faktor yang dapat mempengaruhi jumlah unit yang akan dibeli oleh nasabah.

\section{METODE PENELITIAN}

Tahapan penelitian yang dilakukan adalah sebagai berikut: 
Rini Cahyandari, Riva Lesta Ariany,

Tika Karlina Rachmawati, Nurul Hidayah Eka Putri,

Hasniah Aliah, Rahayu Kariadinata, Adam Malik

1. Mengunjungi dan mewawancara pihak perusahaan asuransi yang bersangkutan mengenai ilustrasi data yang diberikan oleh pihak perusahaan asuransi.

2. Menerjemahkan ilustrasi data yang diberikan oleh pihak perusahaan asuransi ke dalam persamaan matematika.

3. Membuat model integrasi berdasarkan ilustrasi data yang diberikan oleh pihak perusahaan asuransi.

4. Melakukan partisi dana manfaat tambahan dengan menggunakan dana tabarru.

5. Mencari faktor yang mempengaruhi jumlah unit yang akan dibeli oleh nasabah dengan menyebar kuesioner ke nasabah program asuransi tersebut.

6. Mengolah hasil kuesioner dengan menggunakan SPSS.

\section{HASIL DAN PEMBAHASAN}

Berikut merupakan ilustrasi data Asuransi Mitra Mabrur Plus AJB Bumiputera 1912 yang telah diperoleh sebelumnya:

Usia Pemegang Polis : 38 Tahun

Kontrak Keikutsertaan : 5 Tahun

Dana Klaim Kematian : : Rp. 9.000.000

Tingkat Investasi $\quad: 5 \%$

Keuntungan Bagi Hasil $\quad: 70 \%$

Hasil dan pembahasan berisi hasil analisis fenomena di wilayah penelitian yang relevan dengan tema kajian. Hasil penelitian hendaknya dibandingkan dengan teori dan temuan penelitian yang relevan.

Tabel 1. Ilustrasi Data Asuransi Mitra Mabrur Plus

\begin{tabular}{lllllll}
\hline No & \multicolumn{1}{c}{ Keterangan } & \multicolumn{5}{c}{ Bulan Polis } \\
& & $\mathbf{1 - 1 2}$ & $\mathbf{1 3 - 2 4}$ & $\mathbf{2 5 - 3 6}$ & \multicolumn{1}{c}{$\mathbf{3 7 - 4 8}$} & \multicolumn{1}{c}{$\mathbf{4 9 - 6 0}$} \\
\hline 1 & Kontribusi Perbulan & 150.000 & 150.000 & 150.000 & 150.000 & 150.000 \\
2 & Tabarru Dasar & 11.205 & 11.205 & 11.205 & 11.205 & 11.205 \\
3 & Ujrah & 29.025 & 17.760 & 14.001 & 14.001 & 14.001 \\
4 & Personal Account & 109.770 & 121.035 & 124.785 & 124.785 & 124.785 \\
\hline
\end{tabular}

Tabel 2. Ilustrasi Data Dana Manfaat yang Diperoleh

\begin{tabular}{lccccc}
\hline \multicolumn{1}{c}{ Keterangan } & $\mathbf{1}$ & $\mathbf{2}$ & Tahun Polis & $\mathbf{4}$ & $\mathbf{5}$ \\
\hline Premi Terkumpul & 1.800 .000 & 3.600 .000 & 5.400 .000 & 7.200 .000 & 9.000 .000 \\
Tabarru Terkumpul & 134.460 & 268.920 & 403.380 & 537.840 & 672.300 \\
Personal Account & 1.317 .240 & 2.769 .660 & 4.267 .080 & 5.764 .500 & 7.261 .920 \\
Terkumpul & $46.103,4$ & $144.655,119$ & $299.065,8482$ & 511.290 .6529 & $783.353,0258$ \\
Bagi Hasil Terkumpul & $1.363 .343,4$ & $2.914 .315,119$ & $4.566 .145,848$ & $6.275 .790,653$ & $8.045 .273,026$ \\
Nilai Tunai & 75,7413 & 80,953 & 84,558 & 87,163 & 89,391 \\
Nilai Tunai terhadap & Premi (\%) & 5.400 .000 & 3.600 .000 & 1.800 .000 & 0 \\
Dana Klaim Kematian & 7.200 .000 & 5.40 .000 & \\
\hline
\end{tabular}

Tabel 3 Ilustrasi Data Dana Manfaat dalam Persamaan Matematika

\section{Keterangan}

Premi Terkumpul $\left(K_{n}\right)$

Tabarru Terkumpul

$\left(T_{n}\right)$

Personal Account Terkumpul

$\left(P_{n}\right)$

Bagi Hasil Terkumpul

$\left(N_{n}\right)$

\section{Tahun Polis}

$\begin{array}{ccc}\mathbf{3} & \mathbf{4} & \mathbf{5} \\ K_{3}=3 * K & K_{4}=4 * K & K_{5}=5 * K \\ T_{3}=T * K_{3} & T_{4}=T * K_{4} & T_{5}=T * K_{5} \\ T_{3}=T *(3 * & T_{4}=T *(4 * & T_{5}=T *(5 * k) \\ K) & K) & P_{5}= \\ P_{3}= & P_{4}= & K \\ P_{2}+(0,8319 * & P_{3}+(0,8319 * & P_{4}+(0,8319 * \\ K) & K) & K \\ N_{3}=0,7 * & N_{4}=0,7 * & N_{5}=0,7 * \\ 0,05 * & 0,05 * & 0,05 *\end{array}$




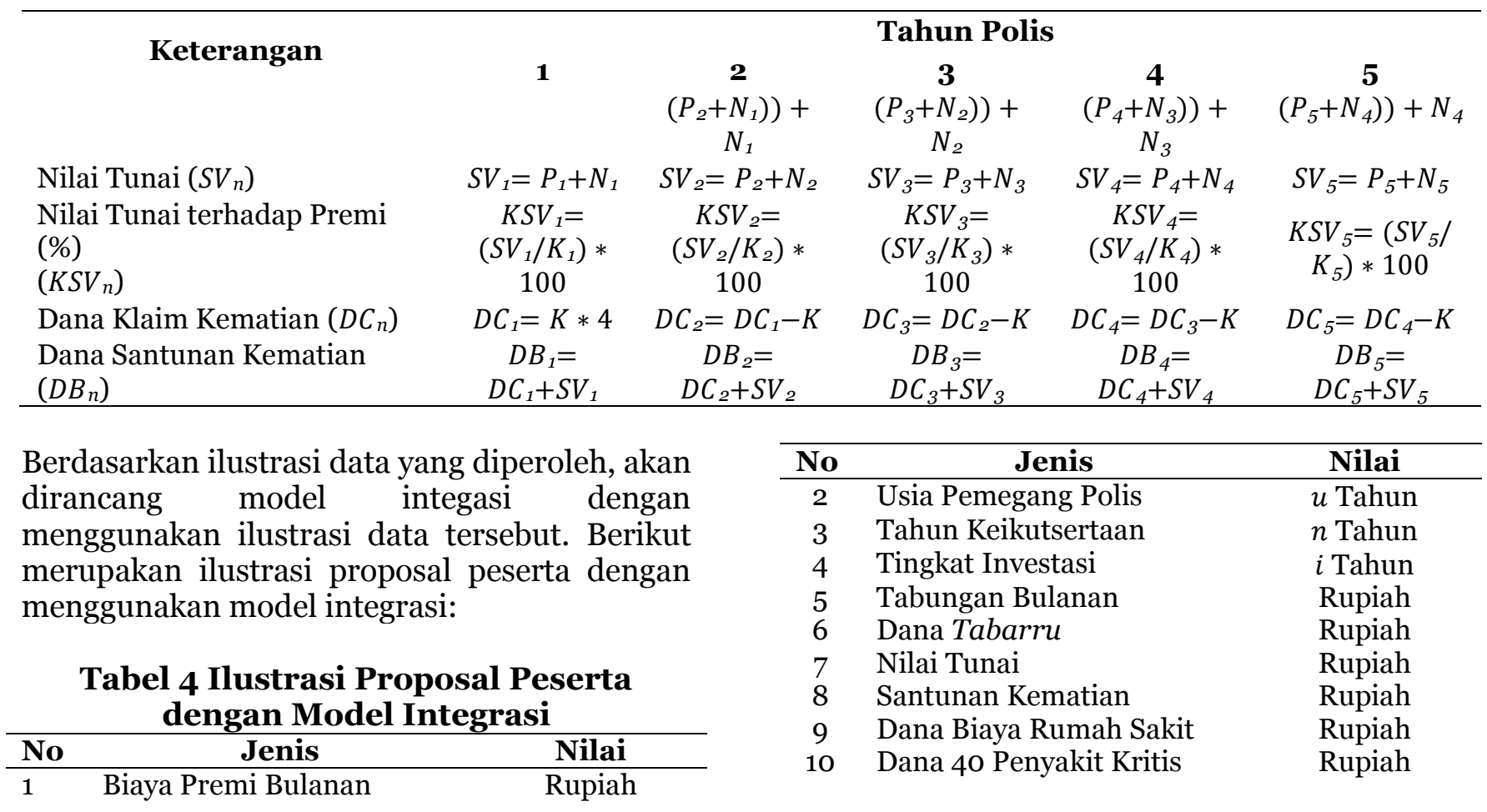


Rini Cahyandari, Riva Lesta Ariany,

Tika Karlina Rachmawati, Nurul Hidayah Eka Putri,

Hasniah Aliah, Rahayu Kariadinata, Adam Malik

Tabel 5 Tabel Model Integrasi Ilustrasi Tabel Premium Life

\begin{tabular}{|c|c|c|c|c|c|c|c|c|c|c|c|c|c|}
\hline Bulan & Usia & $\begin{array}{c}\text { Biaya } \\
\text { Kontri- } \\
\text { busi }\end{array}$ & $\begin{array}{c}\text { Dana } \\
\text { Tabarru }\end{array}$ & Ujrah & $\begin{array}{l}\text { Tabung- } \\
\text { an } \\
\text { Pribadi }\end{array}$ & $\underset{\text { lasi }}{\text { Akumu- }}$ & $\begin{array}{c}\text { Keuntungan } \\
\text { Perbulan }\end{array}$ & $\begin{array}{c}\text { Keuntungan } \\
\text { Pertahun }\end{array}$ & $\begin{array}{l}\text { Nilai } \\
\text { Tunai }\end{array}$ & $\begin{array}{c}\text { Dana } \\
\text { Klaim } \\
\text { Kematian }\end{array}$ & $\begin{array}{c}\text { Biaya 4o } \\
\text { Penyakit } \\
\text { Kritis }\end{array}$ & $\begin{array}{c}\text { Biaya } \\
\text { Rumah } \\
\text { Sakit }\end{array}$ & $\begin{array}{l}\text { Santunan } \\
\text { Kematian }\end{array}$ \\
\hline 1 & 38 & 150.000 & 11.205 & 29.025 & 109.770 & 109770 & 302 & & 110.072 & 9.000.000 & 4.500 .000 & 900.000 & 9.110 .072 \\
\hline 2 & 38 & 150.000 & 11.205 & 29.025 & 109.770 & 219540 & 302 & & 219.842 & 9.000 .000 & 4.500 .000 & 900.000 & 9.219 .842 \\
\hline 3 & 38 & 150.000 & 11.205 & 29.025 & 109.770 & 219540 & 302 & & 219.842 & 9.000.000 & 4.500 .000 & 900.000 & 9.219 .842 \\
\hline 4 & 38 & 150.000 & 11.205 & 29.025 & 109.770 & 219540 & 302 & & 219.842 & 9.000.000 & 4.500 .000 & 900.000 & 9.219 .842 \\
\hline 5 & 38 & 150.000 & 11.205 & 29.025 & 109.770 & 219540 & 302 & & 219.842 & 9.000.000 & 4.500 .000 & 900.000 & 9.219 .842 \\
\hline 6 & 38 & 150.000 & 11.205 & 29.025 & 109.770 & 219540 & 302 & & 219.842 & 9.000.000 & 4.500 .000 & 900.000 & 9.219 .842 \\
\hline 7 & 38 & 150.000 & 11.205 & 29.025 & 109.770 & 219540 & 302 & & 219.842 & 9.000.000 & 4.500 .000 & 900.000 & 9.219 .842 \\
\hline 8 & 38 & 150.000 & 11.205 & 29.025 & 109.770 & 219540 & 302 & & 219.842 & 9.000.000 & 4.500 .000 & 900.000 & 9.219 .842 \\
\hline 9 & 38 & 150.000 & 11.205 & 29.025 & 109.770 & 219540 & 302 & & 219.842 & 9.000.000 & 4.500 .000 & 900.000 & 9.219 .842 \\
\hline 10 & 38 & 150.000 & 11.205 & 29.025 & 109.770 & 219540 & 302 & & 219.842 & 9.000.000 & 4.500 .000 & 900.000 & 9.219 .842 \\
\hline 11 & 38 & 150.000 & 11.205 & 29.025 & 109.770 & 219540 & 302 & & 219.842 & 9.000.000 & 4.500 .000 & 900.000 & $9.225 \cdot 330$ \\
\hline 12 & 38 & 150.000 & 11.205 & 29.025 & 109.770 & 219540 & 302 & 5.489 & $225 \cdot 330$ & 9.000.000 & 4.500 .000 & 900.000 & 9.316 .991 \\
\hline 13 & 39 & 150.000 & 11.205 & 17.760 & 121.035 & 230805 & 86.186 & & 316.991 & 9.000 .000 & 4.500 .000 & 900.000 & 9.328 .256 \\
\hline 14 & 39 & 150.000 & 11.205 & 17.760 & 121.035 & 242070 & 86.186 & & 328.256 & 9.000 .000 & 4.500 .000 & 900.000 & 9.328 .256 \\
\hline 15 & 39 & 150.000 & 11.205 & 17.760 & 121.035 & 242070 & 86.186 & & 328.256 & 9.000.000 & 4.500 .000 & 900.000 & 9.328 .256 \\
\hline 16 & 39 & 150.000 & 11.205 & 17.760 & 121.035 & 242070 & 86.186 & & 328.256 & 9.000 .000 & 4.500 .000 & 900.000 & 9.328 .256 \\
\hline 17 & 39 & 150.000 & 11.205 & 17.760 & 121.035 & 242070 & 86.186 & & 328.256 & 9.000 .000 & 4.500 .000 & 900.000 & 9.328 .256 \\
\hline 18 & 39 & 150.000 & 11.205 & 17.760 & 121.035 & 242070 & 86.186 & & 328.256 & 9.000.000 & 4.500 .000 & 900.000 & 9.328 .256 \\
\hline 19 & 39 & 150.000 & 11.205 & 17.760 & 121.035 & 242070 & 86.186 & & 328.256 & 9.000.000 & 4.500 .000 & 900.000 & 9.328 .256 \\
\hline 20 & 39 & 150.000 & 11.205 & 17.760 & 121.035 & 242070 & 86.186 & & 328.256 & 9.000.000 & 4.500 .000 & 900.000 & 9.328 .256 \\
\hline 21 & 39 & 150.000 & 11.205 & 17.760 & 121.035 & 242070 & 86.186 & & 328.256 & 9.000 .000 & 4.500 .000 & 900.000 & 9.328 .256 \\
\hline 22 & 39 & 150.000 & 11.205 & 17.760 & 121.035 & 242070 & 86.186 & & 328.256 & 9.000.000 & 4.500 .000 & 900.000 & 9.328 .256 \\
\hline 23 & 39 & 150.000 & 11.205 & 17.760 & 121.035 & 242070 & 86.186 & & 328.256 & 9.000 .000 & 4.500 .000 & 900.000 & 9.328 .256 \\
\hline 24 & 39 & 150.000 & 11.205 & 17.760 & 121.035 & 242070 & 86.186 & 6.052 & 334.307 & 9.000 .000 & 4.500 .000 & 900.000 & 9.334 .307 \\
\hline 25 & 40 & 150.000 & 11.205 & 14.401 & 124.785 & 245820 & 127.722 & & 373.542 & 9.000 .000 & 4.500 .000 & 900.000 & $9 \cdot 373 \cdot 542$ \\
\hline 26 & 40 & 150.000 & 11.205 & 14.401 & 124.785 & 249570 & 127.722 & & 377.292 & 9.000 .000 & 4.500 .000 & 900.000 & $9 \cdot 377.292$ \\
\hline 27 & 40 & 150.000 & 11.205 & 14.401 & 124.785 & 249570 & 127.722 & & 377.292 & 9.000.000 & 4.500 .000 & 900.000 & 9.377 .292 \\
\hline
\end{tabular}


AJB Bumiputera 1912 dengan Mempartisi Dana Tabarru

\begin{tabular}{|c|c|c|c|c|c|c|c|c|c|c|c|c|c|}
\hline Bulan & Usia & $\begin{array}{c}\text { Biaya } \\
\text { Kontri- } \\
\text { busi }\end{array}$ & $\begin{array}{c}\text { Dana } \\
\text { Tabarru }\end{array}$ & Ujrah & $\begin{array}{c}\text { Tabung- } \\
\text { an } \\
\text { Pribadi }\end{array}$ & $\underset{\text { lasi }}{\text { Akumu- }}$ & $\begin{array}{c}\text { Keuntungan } \\
\text { Perbulan }\end{array}$ & $\begin{array}{c}\text { Keuntungan } \\
\text { Pertahun }\end{array}$ & $\begin{array}{l}\text { Nilai } \\
\text { Tunai }\end{array}$ & $\begin{array}{c}\text { Dana } \\
\text { Klaim } \\
\text { Kematian }\end{array}$ & $\begin{array}{c}\text { Biaya 4o } \\
\text { Penyakit } \\
\text { Kritis }\end{array}$ & $\begin{array}{c}\text { Biaya } \\
\text { Rumah } \\
\text { Sakit }\end{array}$ & $\begin{array}{l}\text { Santunan } \\
\text { Kematian }\end{array}$ \\
\hline 28 & 40 & 150.000 & 11.205 & 14.401 & 124.785 & 249570 & 127.722 & & 377.292 & 9.000.000 & 4.500 .000 & 900.000 & $9 \cdot 377.292$ \\
\hline 29 & 40 & 150.000 & 11.205 & 14.401 & 124.785 & 249570 & 127.722 & & 377.292 & 9.000 .000 & 4.500 .000 & 900.000 & 9.377 .292 \\
\hline 30 & 40 & 150.000 & 11.205 & 14.401 & 124.785 & 249570 & 127.722 & & 377.292 & 9.000.000 & 4.500 .000 & 900.000 & $9 \cdot 377.292$ \\
\hline 31 & 40 & 150.000 & 11.205 & 14.401 & 124.785 & 249570 & 127.722 & & 377.292 & 9.000.000 & 4.500 .000 & 900.000 & 9.377 .292 \\
\hline 32 & 40 & 150.000 & 11.205 & 14.401 & 124.785 & 249570 & 127.722 & & 377.292 & 9.000 .000 & 4.500 .000 & 900.000 & 9.377 .292 \\
\hline 33 & 40 & 150.000 & 11.205 & 14.401 & 124.785 & 249570 & 127.722 & & 377.292 & 9.000 .000 & 4.500 .000 & 900.000 & $9 \cdot 377.292$ \\
\hline 34 & 40 & 150.000 & 11.205 & 14.401 & 124.785 & 249570 & 127.722 & & 377.292 & 9.000 .000 & 4.500 .000 & 900.000 & $9 \cdot 377.292$ \\
\hline 35 & 40 & 150.000 & 11.205 & 14.401 & 124.785 & 249570 & 127.722 & & 377.292 & 9.000.000 & 4.500 .000 & 900.000 & 9.377 .292 \\
\hline 36 & 40 & 150.000 & 11.205 & 14.401 & 124.785 & 249570 & 127.722 & 6.239 & 383.531 & 9.000 .000 & 4.500 .000 & 900.000 & 9.383 .531 \\
\hline 37 & 41 & 150.000 & 11.205 & 14.401 & 124.785 & 249570 & 146.483 & & 396.053 & 9.000.000 & 4.500 .000 & 900.000 & 9.396.053 \\
\hline 38 & 41 & 150.000 & 11.205 & 14.401 & 124.785 & 249570 & 146.483 & & 396.053 & 9.000 .000 & 4.500 .000 & 900.000 & 9.396.053 \\
\hline 39 & 41 & 150.000 & 11.205 & 14.401 & 124.785 & 249570 & 146.483 & & 396.053 & 9.000.000 & 4.500 .000 & 900.000 & 9.396.053 \\
\hline 40 & 41 & 150.000 & 11.205 & 14.401 & 124.785 & 249570 & 146.483 & & 396.053 & 9.000 .000 & 4.500 .000 & 900.000 & 9.396 .053 \\
\hline 41 & 41 & 150.000 & 11.205 & 14.401 & 124.785 & 249570 & 146.483 & & 396.053 & 9.000 .000 & 4.500 .000 & 900.000 & 9.396 .053 \\
\hline 42 & 41 & 150.000 & 11.205 & 14.401 & 124.785 & 249570 & 146.483 & & 396.053 & 9.000 .000 & 4.500 .000 & 900.000 & 9.396.053 \\
\hline 43 & 41 & 150.000 & 11.205 & 14.401 & 124.785 & 249570 & 146.483 & & 396.053 & 9.000 .000 & 4.500 .000 & 900.000 & 9.396 .053 \\
\hline 44 & 41 & 150.000 & 11.205 & 14.401 & 124.785 & 249570 & 146.483 & & 396.053 & 9.000 .000 & 4.500 .000 & 900.000 & 9.396 .053 \\
\hline 45 & 41 & 150.000 & 11.205 & 14.401 & 124.785 & 249570 & 146.483 & & 396.053 & 9.000.000 & 4.500 .000 & 900.000 & 9.396.053 \\
\hline 46 & 41 & 150.000 & 11.205 & 14.401 & 124.785 & 249570 & 146.483 & & 396.053 & 9.000 .000 & 4.500 .000 & 900.000 & 9.396 .053 \\
\hline 47 & 41 & 150.000 & 11.205 & 14.401 & 124.785 & 249570 & 146.483 & & 396.053 & 9.000.000 & 4.500 .000 & 900.000 & 9.396 .053 \\
\hline 48 & 41 & 150.000 & 11.205 & 14.401 & 124.785 & 249570 & 146.483 & 6.239 & 402.292 & 9.000 .000 & 4.500 .000 & 900.000 & 9.402 .292 \\
\hline 49 & 42 & 150.000 & 11.205 & 14.401 & 124.785 & 249570 & 153.634 & & 403.204 & 9.000.000 & 4.500 .000 & 900.000 & 9.403 .204 \\
\hline 50 & 42 & 150.000 & 11.205 & 14.401 & 124.785 & 249570 & 153.634 & & 403.204 & 9.000 .000 & 4.500 .000 & 900.000 & 9.403 .204 \\
\hline 51 & 42 & 150.000 & 11.205 & 14.401 & 124.785 & 249570 & 153.634 & & 403.204 & 9.000 .000 & 4.500 .000 & 900.000 & 9.403 .204 \\
\hline 52 & 42 & 150.000 & 11.205 & 14.401 & 124.785 & 249570 & 153.634 & & 403.204 & 9.000 .000 & 4.500 .000 & 900.000 & 9.403 .204 \\
\hline 53 & 42 & 150.000 & 11.205 & 14.401 & 124.785 & 249570 & 153.634 & & 403.204 & 9.000.000 & 4.500 .000 & 900.000 & 9.403 .204 \\
\hline 54 & 42 & 150.000 & 11.205 & 14.401 & 124.785 & 249570 & 153.634 & & 403.204 & 9.000 .000 & 4.500 .000 & 900.000 & 9.403 .204 \\
\hline 55 & 42 & 150.000 & 11.205 & 14.401 & 124.785 & 249570 & 153.634 & & 403.204 & 9.000 .000 & 4.500 .000 & 900.000 & 9.403 .204 \\
\hline 56 & 42 & 150.000 & 11.205 & 14.401 & 124.785 & 249570 & 153.634 & & 403.204 & 9.000.000 & 4.500 .000 & 900.000 & 9.403 .204 \\
\hline
\end{tabular}

Jurnal Analisa Vol. 4 No. 2 Desember 2018: 104-115 
Rini Cahyandari, Riva Lesta Ariany,

Tika Karlina Rachmawati, Nurul Hidayah Eka Putri,

Hasniah Aliah, Rahayu Kariadinata, Adam Malik

\begin{tabular}{|c|c|c|c|c|c|c|c|c|c|c|c|c|c|}
\hline Bulan & Usia & $\underset{\text { Kontri- }}{\text { Busi }}$ - & $\begin{array}{c}\text { Dana } \\
\text { Tabarru }\end{array}$ & Ujrah & $\begin{array}{c}\text { Tabung- } \\
\text { an } \\
\text { Pribadi }\end{array}$ & $\underset{\text { lasi }}{\text { Akumu- }}$ & $\begin{array}{c}\text { Keuntungan } \\
\text { Perbulan }\end{array}$ & $\begin{array}{c}\text { Keuntungan } \\
\text { Pertahun }\end{array}$ & $\begin{array}{l}\text { Nilai } \\
\text { Tunai }\end{array}$ & 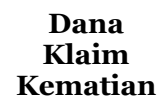 & $\begin{array}{c}\text { Biaya 4o } \\
\text { Penyakit } \\
\text { Kritis }\end{array}$ & $\begin{array}{c}\text { Biaya } \\
\text { Rumah } \\
\text { Sakit }\end{array}$ & $\begin{array}{l}\text { Santunan } \\
\text { Kematian }\end{array}$ \\
\hline 57 & 42 & 150.000 & 11.205 & 14.401 & 124.785 & 249570 & 153.634 & & 403.204 & 9.000 .000 & 4.500 .000 & 900.000 & 9.403 .204 \\
\hline 58 & 42 & 150.000 & 11.205 & 14.401 & 124.785 & 249570 & 153.634 & & 403.204 & 9.000 .000 & 4.500 .000 & 900.000 & 9.403 .204 \\
\hline 59 & 42 & 150.000 & 11.205 & 14.401 & 124.785 & 249570 & 153.634 & & 403.204 & 9.000.000 & 4.500 .000 & 900.000 & 9.403 .204 \\
\hline 60 & 42 & 150.000 & 11.205 & 14.401 & 124.785 & 249570 & 153.634 & 6.239 & 403.204 & 9.000.000 & 4.500 .000 & 900.000 & 9.409 .443 \\
\hline
\end{tabular}

Tabel 6 Tabel Model Integrasi Persamaan Matematika Ilustrasi Premium Life

\begin{tabular}{|c|c|c|c|c|c|c|c|c|c|c|c|c|c|}
\hline Bulan & Usia & $\begin{array}{c}\text { Biaya } \\
\text { Kontri- } \\
\text { busi }\end{array}$ & $\begin{array}{c}\text { Dana } \\
\text { Taba- } \\
\text { rru }\end{array}$ & Ujrah & $\begin{array}{c}\text { Tabu- } \\
\text { ngan } \\
\text { Pribadi }\end{array}$ & Akumulasi & $\begin{array}{l}\text { Keuntung- } \\
\text { an } \\
\text { Perbulan }\end{array}$ & $\begin{array}{c}\text { Keuntu- } \\
\text { ngan } \\
\text { Pertahun }\end{array}$ & $\begin{array}{l}\text { Nilai } \\
\text { Tunai }\end{array}$ & $\begin{array}{c}\text { Dana } \\
\text { Klaim } \\
\text { Kematian }\end{array}$ & $\begin{array}{c}\text { Biaya 4o } \\
\text { Penya- } \\
\text { kit } \\
\text { Kritis }\end{array}$ & $\begin{array}{c}\text { Biaya } \\
\text { Rumah } \\
\text { Sakit }\end{array}$ & $\begin{array}{l}\text { Santu- } \\
\text { nan } \\
\text { Kemati- } \\
\text { an }\end{array}$ \\
\hline 1 & 38 & $K$ & $\begin{array}{l}0.0747 \\
* K\end{array}$ & $\begin{array}{l}0.1935 \\
* K\end{array}$ & $\begin{array}{l}0.7318 \\
* K\end{array}$ & 109.770 & 302 & & 110.072 & $(K * 12) * 5$ & $\begin{array}{l}0.5 \\
*((K \\
* 12) * 5)\end{array}$ & $\begin{array}{l}0.1 \\
*((K \\
* 12) * 5)\end{array}$ & $\begin{array}{l}((K * 12) \\
* 5) \\
+110.072\end{array}$ \\
\hline $2-11$ & 38 & K & $\begin{array}{l}0.0747 \\
* K\end{array}$ & $\begin{array}{l}0.1935 \\
* K\end{array}$ & $\begin{array}{l}0.7318 \\
* K\end{array}$ & $C_{1}$ & $D_{1}$ & & $C_{1}+D_{1}$ & $(K * 12) * 5$ & $\begin{array}{l}0.5 \\
*((K \\
* 12) * 5)\end{array}$ & $\begin{array}{l}0.1 \\
*((K \\
* 12) * 5)\end{array}$ & $\begin{array}{c}((K * \\
12) * 5)+( \\
\left.C_{1}+D_{1}\right) \\
((K *\end{array}$ \\
\hline 12 & 38 & K & $\begin{array}{l}0.0747 \\
* K\end{array}$ & $\begin{array}{l}0.1935 \\
* K\end{array}$ & $\begin{array}{l}0.7318 \\
* K\end{array}$ & $\begin{array}{l}(0.7318 * K) \\
+(0.8069 \\
* K)\end{array}$ & $D_{1}$ & $\begin{array}{l}0.05 \\
*(0.7318 \\
* K)\end{array}$ & $\begin{array}{c}\left(C_{1}+D_{1)}+\right. \\
(0.05 * \\
(0.7318 * \\
K))\end{array}$ & $(K * 12) * 5$ & $\begin{array}{l}0.5 \\
*((K \\
* 12) * 5)\end{array}$ & $\begin{array}{l}0.1 \\
*((K \\
* 12) * 5)\end{array}$ & $\begin{array}{c}12) * 5)+ \\
\left(C_{1}+D_{1)+}+\right. \\
(0.05 * \\
(0.7318 * \\
K)) \\
((K *\end{array}$ \\
\hline 13 & 39 & $K$ & $\begin{array}{l}0.0747 \\
* K\end{array}$ & $\begin{array}{l}0.1184 \\
* K\end{array}$ & $\begin{array}{l}0.8069 \\
* K\end{array}$ & $C_{2}$ & $D_{2}$ & & $\begin{array}{c}(0.7318 * \\
K)+ \\
(0.8069 * \\
K)+D_{2}\end{array}$ & $(K * 12) * 5$ & $\begin{array}{l}0.5 \\
*((K \\
* 12) * 5)\end{array}$ & $\begin{array}{l}0.1 \\
*((K \\
* 12) * 5)\end{array}$ & $\begin{array}{c}12) * 5)+ \\
((0.7318 * \\
K)+ \\
(0.8069 * \\
\left.\left.K)+D_{2}\right)\right)\end{array}$ \\
\hline $14-23$ & 39 & $K$ & $\begin{array}{l}0.0747 \\
* K\end{array}$ & $\begin{array}{l}0.1184 \\
* K\end{array}$ & $\begin{array}{l}0.8069 \\
* K\end{array}$ & $C_{2}$ & $D_{2}$ & & $C_{2}+D_{2}$ & $(K * 12) * 5$ & $\begin{array}{l}0.5 \\
*((K \\
* 12) * 5)\end{array}$ & $\begin{array}{l}0.1 \\
*((K \\
* 12) * 5)\end{array}$ & $\begin{array}{c}((K * \\
12) * 5)+ \\
\left(C_{2}+D_{2}\right)\end{array}$ \\
\hline 24 & 39 & K & $\begin{array}{l}0.0747 \\
* K\end{array}$ & $\begin{array}{l}0.1184 \\
* K\end{array}$ & $\begin{array}{l}0.8069 \\
* K\end{array}$ & $C_{2}$ & $D_{2}$ & $\begin{array}{l}0.05 \\
*(0.8069 \\
* K)\end{array}$ & $\begin{array}{l}\left(C_{2}+D_{2}\right)+( \\
0.05 \\
*(0.8069 \\
* K))\end{array}$ & $(K * 12) * 5$ & $\begin{array}{l}0.5 \\
*((K \\
* 12) * 5)\end{array}$ & $\begin{array}{l}0.1 \\
*((K \\
* 12) * 5)\end{array}$ & $\begin{array}{l}(K * 12) * \\
5)+\left(\left(C_{2}\right.\right. \\
\left.\quad+D_{2}\right)+( \\
0.05 \\
*(0.8069 \\
* K))\end{array}$ \\
\hline 25 & 40 & K & $\begin{array}{l}0.0747 \\
* K\end{array}$ & $\begin{array}{l}0.0934 \\
* K\end{array}$ & $\begin{array}{l}0.8319 \\
* K\end{array}$ & $\begin{array}{l}(0.8069 \\
* K) \\
+(0.8319 \\
* K)\end{array}$ & $D_{3}$ & & $\begin{array}{c}(0.8069 * \\
K)+ \\
(0.8319 * \\
K)+D_{3} \\
\end{array}$ & $(K * 12) * 5$ & $\begin{array}{l}0.5 \\
*((K \\
* 12) * 5)\end{array}$ & $\begin{array}{l}0.1 \\
*((K \\
* 12) * 5)\end{array}$ & $\begin{array}{c}(K * 12) * \\
5+( \\
(0.8069 * \\
K)+ \\
\end{array}$ \\
\hline
\end{tabular}


AJB Bumiputera 1912 dengan Mempartisi Dana Tabarru

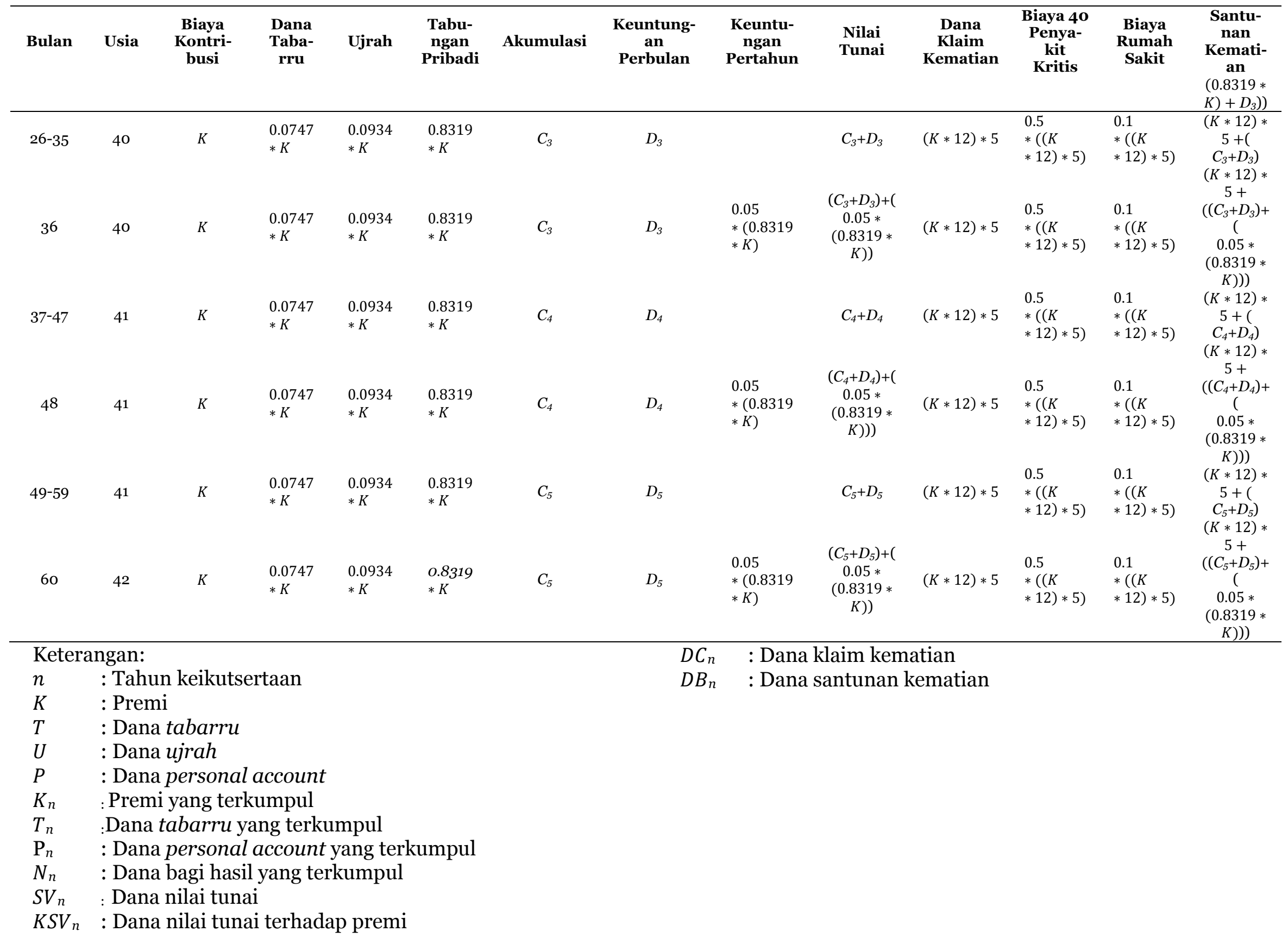


Rini Cahyandari, Riva Lesta Ariany,

Tika Karlina Rachmawati, Nurul Hidayah Eka Putri, Hasniah Aliah, Rahayu Kariadinata, Adam Malik Berikut merupakan istilah yang digunakan, sebagai berikut.

1. Polis merupakan surat perjanjian yang memuat perjanjian asuransi jiwa antara pemegang polis/nasabah dan badan/perusahaan asuransi yang bersangkutan.

2. Premi merupakan sejumlah uang yang harus dubayarkan dalam setiap bulannya selama masa polis aktif.

3. Klaim merupakan tuntutan pembayaran manfaat sesuai dengan ketentuan yang diatur dalam polis asuransi.

4. Nilai tunai merupakan jumlah uang yang harus dibayarkan kepada pemegang polis, jika perjanjian asuransi diakhiri sebelum berakhirnya perjanjian tersebut.

5. Rider (Manfaat) merupakan ketentuan yang melekat pada polis yang memberika manfaat tambahan atau pembatasan.

6. Uang pertanggungan merupakan santunan yang akan dibayarkan jika tertanggung meninggal dunia ketika sebelum masa asuransinya berakhir.

7. Tabarru merupakan merupakan kumpulan dana kebajikan yang telah diniatkan oleh pemegang polis sebagai iuran dana kebajikan dengan tujuan menolong dan saling membantu yang dibayarkan apabila pemegang polis meninggal dunia dan atau pejanjian telah berakhir. Jika ada sulprusdana maka dibagikan kepada peserta, perusahaan dan agen.

Partisi dari biaya premi tahunan dibentuk berdasarkan dari rasio manfaat-manfaat tambahan yang akan diperoleh nasabah. Berdasarkan ilustrasi data yang digunakan, biaya premi yang dibayarkan secara tahunan oleh nasabah adalah sebesar Rp. 1.800.00o,.dan total keseluruhan biaya premi akan dibagi menjadi beberapa bagian berbeda, yaitu dana personal account, dana tunjangan biaya rumah sakit, dana tunjangan apabila mengalami kelumpuhan/cacat dan terserang 40 penyakit kritis, dan dana santunan kematian. Berdasarkan ilustrasi data yang digunakan, dikenakan biaya sebesar Rp. 450.00o,.untuk satu unit. 
Tabel 9 Daftar Item Pertanyaan

\begin{tabular}{cll}
\hline No & Pertanyaan & Variabel \\
\hline 1 & Umur & Kel.Umur \\
2 & Status & Status \\
3 & Pendidikan & Education \\
4 & Pekerjaan & Job \\
5 & Pendapatan & Salary \\
6 & Jumlah Anak & Children \\
7 & Produk asuransi Mitra Mabrur Plus menambahkan manfaat (riders) berupa & Afford \\
& pengcoveran 40 penyakit kritis dan biaya rumah sakit bagi pemegang polis dan ahli & \\
& waris & \\
8 & Berapa banyak unit produk yang akan akan anda beli berdasarkan dengan jumlah & Unit \\
& penghasilan anda perbulan & \\
9 & Apakah Anda setuju dengan rancangan terbaru dari produk Mitra Mabrur Plus? & Risk \\
10 & Menurut Anda apakah rancangan produk ini merupakan rancangan produk Mitra & Earner \\
& Mabrur Plus menjadikan produk ini sebagai produk unggulan yang sesuai dengan & \\
& Semua kategori penghasilan? & \\
\hline
\end{tabular}

Berikut merupakan hasil analisis dari penyebaran kuesioner yang sudah diolah dengan menggunakan SPSS.

Tabel 10 Hasil Olah Data SPSS

\begin{tabular}{|c|c|c|c|c|c|c|}
\hline \multicolumn{7}{|c|}{ Coefficients $^{a}$} \\
\hline & & \multicolumn{2}{|c|}{ Unstandardized Coefficients } & $\begin{array}{l}\text { Standardized } \\
\text { Coefficients }\end{array}$ & \multirow[b]{2}{*}{$\mathrm{t}$} & \multirow[b]{2}{*}{ Sig. } \\
\hline \multicolumn{2}{|c|}{ Model } & $B$ & Std. Error & Beta & & \\
\hline 1 & (Constant) & 1.653 & .901 & & 1.833 & .097 \\
\hline & child & .030 & .138 & .065 & .216 & .833 \\
\hline & Edu & -.220 & .139 & -.455 & -1.589 & .143 \\
\hline & Job & .016 & .047 & .083 & .342 & .739 \\
\hline & Pndpn & .098 & .158 & .168 & .619 & .550 \\
\hline & No.6 & 1.214 & .553 & .836 & 2.198 & .053 \\
\hline & No.8 & -.066 & .771 & -.038 & -.085 & .934 \\
\hline & No.9 & -.365 & .607 & -.209 & -.601 & .561 \\
\hline
\end{tabular}

Berdasarkan tabel diatas nilai beta terbesar adalah kesediaan untuk menambah jumlah unit dengan nilai sebesar o.836. Hal ini menunjukkan bahwa kesediaan untuk menambah jumlah unit merupakan faktor yang paling berpengaruh dalam mempengaruhi nasabah untuk menambah jumlah unit.

\section{KESIMPULAN}

Pengembangan produk asuransi Mitra Mabrur Plus dilakukan dengan cara mempartisi dana tabarru yang diperoleh dari hasil pembayaran premi yang dilakukan secara rutin berkala. Pengembangan produk asuransi dilakukan untuk memperoleh manfaat tambahan bagi nasabah pemegang polis dan ahli warisnya. Manfaat tambahan yang diperoleh adalah antara lain berupa pengcoveran biaya rumah sakit (berlaku untuk nasabah pemegang polis dan ahli waris), pengcoveran biaya terserang 40 macam penyakit kritis (berlaku untuk nasabah pemegang polis dan ahli waris), serta santunan kematian (berlaku apabila nasabah pemegang polis meninggal ketika masih terikat kontrak asuransi). Dana santunan kematian akan diberikan kepada ahli waris.

Berdasarkan ilustrasi data yang digunakan, dikenakan biaya sebesar Rp.450.00o untuk satu unit. Berdasarkan tabel hasil partisi, total keseluruhan untuk setiap bagian adalah 32. Oleh karena itu, setiap partisi dari dana tabarru yang digunakan pada ilustrasi data adalah sebesar Rp.350,16.Untuk respon dari pemegang polis sendiri adalah kesediaan untuk menambah jumlah unit merupakan faktor yang paling berpengaruh dalam mempengaruhi nasabah untuk menambah jumlah unit.

\section{DAFTAR PUSTAKA}

Cahyandari, R., Ariany, R. L., \& Sukono. (2018). Optimization of hybrid model on hajj travel. IOP Conference Series: Materials Science and Engineering, 332, 12042. https://doi.org/10.1088/1757- 
Rini Cahyandari, Riva Lesta Ariany,

Tika Karlina Rachmawati, Nurul Hidayah Eka Putri, Hasniah Aliah, Rahayu Kariadinata, Adam Malik 899X/332/1/012042

Ghazali, P. L. (2011). Mathematical Modelling in Family Takaful.pdf.

Ghazali, P. L. (2015). Optimization of Integration Model for All. Journal of Applied Sciences Research, 9(39), 18991909.

Ghazali, P. L., Mohd, I., Muhamad, W., Ahmad, A. W., \& Mamat, M. (2012).

Implementation of Integration Model for All. Journal of Applied Sciences Research 8 (3): 1802-1812, ISSN: 1819-544X., 8(3), 1802-1812.
Puspitasari, N. (2011). Sejarah dan Perkembangan Asuransi Islam serta Perbedaannya dengan Asuransi Konvensional. JEAM, X(1), 1412-5366.

Sula, M. . (2004). Asuransi Syariah (Life and General) Konsep dan Sistem Operasional. Jakarta: Gema Insani. 